\title{
Analysis of Cultural Resources of Taoist Landscape Architecture in Qingcheng Mountain
}

\author{
Tan Huicun \\ Tourism College of Sichuan Agricultural University \\ *email: 729836593@qq.com
}

\begin{abstract}
Qingcheng Mountain as a Taoist mountain, Sichuan important tourist destination, rich in tourism and cultural resources. Qingcheng Mountain as a national 5A-class tourist attractions, which contains the rich Taoist landscape cultural resources constitute Qingchengshan tourism cultural resources is an important part of the tourists is an important source of attractiveness.
\end{abstract}

Keywords: Qingcheng Mountain, Taoist landscape, Cultural resources, Tourism.

\section{Introduction}

Qingcheng Mountain as the fifth cave of Taoism, after the operation of it has a rich Taoist landscape cultural resources. It is important to enhance the cultural experience of tourists in the tourism experience, and to explore its inner cultural connotation, to enhance the visibility and attractiveness of Qingcheng Mountain and to enhance the cultural experience of tourists in tourism.

\section{A Survey of Taoist Landscape Cultural Resources in Qingcheng Mountain}

Taoist landscape, it refers to the Taoist architecture as the core component of the unified natural space, socio-economic elements of the overall characteristics of the collection and space system.

Qingcheng Mountain as one of the birthplace of Taoism, the mountain area is rich in Taoist landscape cultural resources ${ }^{[1]}$. In the temple, gong, guan, dian, tang, miao, tai, lou, ge, guan, she, xuan, zhai, lang, que, men, tan, yu, ta, xie, fang, qiao became a part of the landscape of the Qingcheng Mountain Taoism.It greatly enriched the Qingcheng Mountain Taoist landscape cultural resources and connotations. "Qingcheng world quiet" embodies the Taoist mood of the natural landscape in any of the Qingcheng Mountain can feel profound. And many of the cultural landscape is reflected in the Taoist philosophy of philosophy.

Qingcheng Mountain developed the scenic areas, including the former mountain and after the mountain, the distribution of the former mountain to the main cultural landscape, after the mountain to the natural landscape. Qingcheng Mountain as a Taoist mountain, regardless of its natural landscape or cultural landscape, are full of Taoist culture of color.

Qingcheng hills and cloth has a large number of Taoist culture associated with the landscape, "poor Feixiang not forget" the Feixiang concept, the legendary Zhao Gongming possession of the golden whip of the golden whip rock, Taoist founder Zhang Ling wife Sun Lady practiced the Lady of the Cave. The late Qing Dynasty from the temple to the temple of the Taiqing Gong, mysterious and full of Taoist mythology of the fairy cave, where all these views are embodied in the thick Taoist color, and the mountain after the quiet natural environment together to create a Taoist Unique human and natural harmony in the mood.

The Taoist landscape of Qingcheng 's front mountain is mainly built by palace. The palace of the temple to Tianzhe as the core, including the Palace of Jianfu, Shangqing Palace, the founder of the temple, the palace of the Yuanming, Laojun Pavilion, Yuqing Gong, Chaoyang Cave, natural picture Square, etc., and surrounded by high mountain, Longju Mountain, Qiyuan Mountain, Zhang Ren Shan, Bao Yuan Shan will be around the meantime. The palace of the building itself is the product of the development process of Taoism, at the same time, its building within the palace, hall, pavilion, Taiwan, floor, Court and other specific attractions is rich in Taoist cultural color. Qingcheng Mountain Taoist landscape cultural resources distribution as shown in Table 1. 
Table 1. The Distribution of Taoist Landscape Cultural Resources in Qingcheng Mountain

\begin{tabular}{|c|c|c|c|}
\hline & $\begin{array}{l}\text { Landscape } \\
\text { Name }\end{array}$ & $\begin{array}{l}\text { Taoist } \\
\text { Characters And } \\
\text { Allusions }\end{array}$ & $\begin{array}{c}\text { Related Taoist Landscape Cultural } \\
\text { Resources }\end{array}$ \\
\hline \multirow{11}{*}{$\begin{array}{l}\text { Before } \\
\text { The } \\
\text { Mountain }\end{array}$} & Tian-Shi Dong & Zhang Ling-Ji & $\begin{array}{l}\text { San Qing Dian, Zodiac Relief, Huang } \\
\text { Di Dian }\end{array}$ \\
\hline & Jian-Fu Gong & $\begin{array}{l}\text { Ning Feng, Du } \\
\text { Guang-Ting }\end{array}$ & $\begin{array}{l}\text { Zhuang Ren Dian, Qingchengshan } \\
\text { Long Association, Shui Xin Ting }\end{array}$ \\
\hline & $\begin{array}{l}\text { Shang-Qing } \\
\text { Gong }\end{array}$ & $\begin{array}{l}\text { Tai Shang Lao } \\
\text { Jun, LV } \\
\text { Chun-Yang, } \\
\text { Zhang } \\
\text { San-Feng }\end{array}$ & $\begin{array}{lcr}\text { Carved Stone, Laojun Dian, } \\
\text { Mandarin Duck Wells, Moral } \\
\text { Church, Wenwu Temple, Ma Gu Pool }\end{array}$ \\
\hline & Zu-Shi Dian & $\begin{array}{l}\text { Zhen Wu Da } \\
\text { Di, Zhang } \\
\text { San-Feng }\end{array}$ & $\begin{array}{l}\text { BathDan Wells, Reading Desk, } \\
\text { Yunsong Tower, Ling Guan Dian }\end{array}$ \\
\hline & $\begin{array}{l}\text { Yuan-Ming } \\
\text { Gong }\end{array}$ & $\begin{array}{lr}\text { Yuan } & \text { Ming } \\
\text { Dao } & \text { Mu } \\
\text { Tian-Zun } & \\
\end{array}$ & $\begin{array}{l}\text { Lvzu Dong, LingZu Temple, } \\
\text { Laojundian, Dou Mu Dian }\end{array}$ \\
\hline & Lao-Jun Ge & $\begin{array}{l}\text { Tai Shang Lao } \\
\text { Jun }\end{array}$ & Tai Shang Lao Lun Colossus \\
\hline & Yu-Qing Gong & $\begin{array}{l}\text { Tian Huang } \\
\text { Zhen-Ren }\end{array}$ & Natural Spring Water \\
\hline & $\begin{array}{l}\text { Chao-Yang } \\
\text { Dong }\end{array}$ & Ning Feng & $\begin{array}{l}\text { Ning Feng Jun, Lv Zu, Qiu Zu, San } \\
\text { Guan Statue }\end{array}$ \\
\hline & $\begin{array}{ll}\text { Tian Ran } & \mathrm{Tu} \\
\text { Hua Fang } & \end{array}$ & & $\begin{array}{l}\text { Tian He Guan , Yao Wang Dian, } \\
\text { Laojun Dian }\end{array}$ \\
\hline & Quan-Zhendian & $\begin{array}{l}\text { Wang } \\
\text { Zhong-Yang }\end{array}$ & $\begin{array}{l}\text { Ci Hang Dian, Qi Zhen Dian, Wu Zu } \\
\text { Lou }\end{array}$ \\
\hline & $\begin{array}{l}\text { Zhang-Ren } \\
\text { Guan }\end{array}$ & $\begin{array}{l}\text { Wang Pei-Xiu、 } \\
\text { Lv Jing-Xu }\end{array}$ & $\begin{array}{l}\text { San Huang Tai, Ning Feng Stone } \\
\text { Picture, Tomb Of Mu Zhi Qiang }\end{array}$ \\
\hline \multirow{5}{*}{$\begin{array}{l}\text { After The } \\
\text { Mountain }\end{array}$} & Fei-Xian Guan & $\begin{array}{l}\text { "Poor Feixiang } \\
\text { Not Forget The } \\
\text { Vulgar" }\end{array}$ & Fei Xian Ting, Chan Shi Yan \\
\hline & Jin-Bian Yan & $\begin{array}{l}\text { Zhao } \\
\text { Gong-Ming }\end{array}$ & Jin Bian Ting, Ba Gua Tai \\
\hline & Shen-Mu Dong & $\begin{array}{l}\text { Mrs. Zhang 'S } \\
\text { Wife }\end{array}$ & The Image Of The Virgin \\
\hline & Tai-Qing Gong & & San Huang Dian, San Qing Dian \\
\hline & $\begin{array}{l}\text { Shen-Xian } \\
\text { Dong }\end{array}$ & & $\begin{array}{l}\text { Xianxian Gou, Shen Xian Dong, Shen } \\
\text { Xian Gou, Shen Xian Gong, Shen } \\
\text { Xian Shi Lin }\end{array}$ \\
\hline
\end{tabular}

\section{An Analysis of the Cultural Connotations Reflected in the Taoist Landscape of Qingcheng Mountain}

Religion is a cultural phenomenon, tap the connotation of religious culture, design religious tourism development projects, can increase the cultural content of tourism, improve the level of tourism development, and promote the development of tourism. Qingcheng Mountain Taoist landscape in a strong religious and cultural heritage, is the Qingchengshan become one of the four famous Taoist mountains of China an important factor. It is of great theoretical and practical 
significance to further study the cultural connotation of Qingcheng Mountain's tourism resources and to enhance the tourist experience of tourists ${ }^{[2]}$.

Taoism as a native of China's religion, Laozhuang Taoism, immortal thought, yin and yang of the five elements constitute an important part of Taoist culture. Qingcheng Mountain Taoist landscape has a profound expression of this. Taoism "Taoism natural", "back to nature" and other concepts, profoundly reflected in the Taoist landscape and the natural landscape of harmony. Qingcheng Mountain in the Taoist landscape architecture, its overall layout pay attention to the natural, according to the mountain and built, and natural integration, embodies the Taoist "Road law" philosophy. At the same time Taoist temples, building pool pond, mountain forest garden, according to the terrain hidden in the mountains, while the surrounding environment with the integration of architecture, landscape, the surrounding scenery seamless, embodies the harmony between man and nature And Taoism Philosophy of "Harmony between Man and Nature". Taoist pavilions drawn from nature, not fake carvings, and mountain forest spring integration, reflecting the Taoist advocate simple and natural style ${ }^{[3]}$. Taoist temples are selected materials are wood, one for the use of nature, the other reflects the traditional culture of the yin and yang of the five elements said. "Zuozhuan" said "born five things, the people and use, waste can not", the so-called five-material, that is, the traditional five elements of the gold and wood fire and fire soil five kinds of material, the ancient Chinese architectural materials used wood, Natural communication also has a close relationship, that is, "I am one", the integration of man and nature embodies the concept. These philosophy of Taoism combined with nature is in line with the thought of Taoism back to nature, and makes the Taoist landscape of the Qingcheng Mountain both the beauty of humanities and the beauty of nature, and greatly enhance its aesthetic visual experience. This is a visual experience of the Taoist beauty, but also profoundly expressed in the color of the Taoist landscape. Qingcheng Mountain Road to teach the color of the palace to more than black and white as the tone, which is the color of Chinese classical ink painting has the same purpose, but also China's unique aesthetic performance. Famous writer Yu Qiuyu said: "Confucius hundred great, is that they are chosen to become the Chinese people's psychological tone. Confucius is the dignified brown, similar to our skin and the earth, and I was misty gray, Similar to the sky of the snow peak and the old man to be made.

Influenced by the digital concept of Taoist thought, the Taoist temple of Qingcheng Mountain is often built on the three-story stone ladder, and the roofs of Qingcheng Mountain can be seen by the overlapping of one, two and three tiles. The Taoist thought of "Taoism one, life two, two students three, three things" philosophy ${ }^{[4]}$. Taoism by the immortal, witchcraft thought, the ultimate goal of Taoist practice is to practice immortality, Qingcheng Mountain is an important "fairy will be the House." At the same time, in the "fairy man floor" under the concept of the construction of a series of Taoist landscape, as Taoism know the practice of an important place, both need to have a solemn atmosphere, while the requirements of the environment but also quiet and away from the secular world sense. These constitute the Taoist architectural landscape cultural connotation of the quiet and inadvertently and visitors look at the intuitive experience of exposure to wonderland. At the same time, Taoist thought in the longevity and health and longevity of the idea, so that visitors also have a wide range of attraction, which in the invisible tourists to increase the understanding of the cultural connotation of Qingcheng Mountain view of interest. Qingcheng mountain Taoist temple established a long time, with a strong sense of history, but also formed its independent viewing charm. Across the time and space of the Taoist landscape, the history of China has a long history, broad and profound solidification in the Taoist landscape, become the external manifestations of Taoist culture. The location of the Taoist landscape, the layout of the foundation, the architectural form through a seat of Taoist temples, Taoist important figures and their history and Taoism and culture one by one image to show in front of the world.

\section{Exploitation and Utilization of Taoist Landscape Culture Resources in Qingcheng Mountain}

The development and utilization of tourism resources is the process of converting resources into products and even commodities. The development of tourism resources must first understand the 
cultural heritage of tourism resources, from various aspects to explore the cultural connotation of tourism resources to fully demonstrate its charm and value, improve the cultural quality of tourism resources, tourism attractions to enhance the attractiveness and appeal of tourists, Improve the re-interest rate, and create a good economic, social and environmental benefits ${ }^{[5]}$.

The influence of religious landscape resources is closely related to the status of this resource in religion, and the religious circles of the religious factions tend to have a greater impact than other religious tourism landscapes. Qingcheng Mountain as a religious landscape, Taoist Heavenly Master Road where the ancestral home, its reputation is an important reason for its status in the Taoist, Qingcheng Mountain as a Taoist mountain to attract countless tourists come to watch, but the religious landscape resources In the religious and cultural factors, so that people in the tour, in order to get a better experience, we must have a certain religious culture. This is not so easy for ordinary tourists, so how can the abstract religious culture be more intuitive and easier to understand and accept the image of the show before people, so that people get a better travel experience, the Qingcheng Mountain Taoism Landscape culture resources to be more fully and more rational development and utilization, it has become an important thinking of the problem.

First, with the highly developed electronic information, you can build a virtual tour of the scene, with pictures, video, commentary, etc. in the tourists into the mountains before the Qingcheng Mountain distant history, important attractions and cultural connotations one by one show Tourists in the further tour of the Taoist landscape in the religious and cultural characteristics and traditional Taoist culture to understand, in order to enhance the tourist experience, but also to Qingcheng Mountain culture to spread.

Second, with the cultural visualization of the show, through the scene reproduction or book brochures, the Qingcheng Mountain Taoist landscape and the connotation of Taoist culture linked, for example, the establishment of some palace architecture, and Taoism history has been closely linked to the events, Embodies the development of Taoist culture context, as well as the landscape of the architectural pattern, the internal set of Taoist culture that contains the color. To Laojunge as an example, Laojun Ge under the circle, meaning Tianyuan place; layer with octagonal, to show gossip; appearance was tower-shaped, top three round treasure, to show heaven and earth three meaning ${ }^{[6]}$. And then the Qing Dynasty, the Shangqing Gong worship Taoist ancestor Li Laojun, I have statue and "Tao Te Ching" five thousand words woodcut, there Ma Gu pool, mandarin duck wells and other legends ${ }^{[7]}$. These statues, wood carvings, relics are important figures in the history of Taoism, important contributions and famous allusions. These figures in the history of Taoism have an important position in the history of the story and allusions can be through the text, the introduction of the picture so that visitors to the Qingcheng Mountain Taoist landscape cultural connotation has a clear understanding, and not because of the lack of relevant background knowledge of tourists in a hurry And over.

Third, the cultural color of the Taoist landscape can also be manifested through Taoist cultural activities. Many of the Taoist cultural activities are held in the Taoist temple, which also makes the Taoist temple added a bit Taoist solemn and solemn. The development of these religious activities, in turn, further enhanced the Taoist culture of Taoist culture. With religious activities to expand its influence, so that visitors more understanding of the cultural charm of Qingcheng Mountain, to enhance its tourism experience, to expand the visibility of Qingcheng Mountain. At the same time through the experience of the project, so that visitors directly involved in the Taoist activities, or let them live in the Taoist mind, experience the practice and life of Taoist priests, so that they have a more direct contact with Taoism, so they will Culture has a more intuitive and in-depth understanding.

Fourth, the idea of "Taoism and nature" embodied in the thought of architecture of the Qingcheng Mountain temple is coincident with the concept of ecotourism. In the process of watching the Taoist landscape, we will carry out the ecotourism consciousness and promote the harmony between man and nature, and will link the ornament of the humanities and the natural landscape with the ecotourism and promote the development of the ecological tourism of Qingcheng Mountain. 
Fifth, in the scenic area of the new landscape development, especially in the construction of a new palace architecture, we must fully take into account the Taoist cultural factors, so that the old and new landscape architecture and nature can be integrated, and not too abrupt and destroyed The overall cultural atmosphere. So that visitors can feel the Taoist landscape in the cultural landscape, but also can feel the return to the fun of nature, which is the essence of Taoism, is also in the tourist area development must not avoid the problem.

Sixth, religious tourism in addition to the general tourism with the leisure function, but also contribute to the spread of culture and development. The development of Qingcheng Mountain landscape associated with the tourism souvenirs, the Qingcheng Mountain well-known landscape architecture and related cultural resources to micro-mode, pictures, bookmarks and other forms of production into a unique tourist souvenirs, so that the Qingcheng Mountain landscape architecture and its Culture farther to spread. At the same time, the development of tourist souvenirs will also bring objective economic benefits to the local tourism industry.

In general, in the development and utilization of landscape cultural resources in Qingcheng Mountain, the cultural resources and connotations of the landscape culture of Qingcheng Mountain are deeply excavated, and the abstract religious cultural connotation is transformed into intuitive, image tourism resources to attract different tourists, the largest Limit to enhance the tourist experience of tourists in the promotion of Qingcheng Mountain tourism development will also Qingcheng Mountain Taoist landscape culture to be more widely disseminated.

\section{Acknowledgement}

The project is the Sichuan landscape and recreation development research center project: Qingcheng Mountain Taoist landscape cultural resources (project number JGYQ2015013) and 2012 Sichuan Agricultural University Social Science Youth Project: Qingcheng Mountain Taoist culture tourism resources analysis (project number: 0280013) and analysis stage Results.

\section{References}

[1] Bian Jian-ning. The Regional Characteristics and Cultural Connotation of the Remains of Taoist Landscape in Henan Province [J], Journal of San men xia Polytechnic, 2014, (3).

[2] Li Yue-zheng, Yu Jin-guo, Fu Hongzhi. China's regional religious and cultural landscape and its tourism development [J], Human Geography, 2003, (3), 60-63.

[3] http://www.360doc.com/content/12/0822/09/5316526_231649768.shtml.

[4] Yuan Yinzhi, Wei Baoshan. Taoist cultural tourism resources and development [J], Religious Studies, 2004 (4), 140-143.

[5] Xie Chunshan. On the cultural factors of China's tourism landscape fame [J], Journal of Dalian University of Technology (Social Science Edition), 2000, (4).

[6] http://www.360doc.com/content/12/0822/09/5316526_231649768.shtml.

[7] http://www.360doc.com/content/12/0822/09/5316526_231649768.shtml. 